\title{
Online Teaching Resources about Medicinal Plants and Ethnobotany
}

Kristina M. Straus ${ }^{\dagger \neq}$ and Eric H. Chudler ${ }^{\dagger \$ \|}$

${ }^{\dagger}$ Department of Bioengineering, ”Program on the Environment, ${ }^{\S}$ Center for Sensorimotor Neural Engineering, and "Department of Anesthesiology and Pain Medicine, University of Washington, Seattle, WA 98105-6271

\section{INTRODUCTION}

Exploring plant-based medicines and ethnobotany (the scientific field that examines a culture's knowledge, customs, and uses of plants) in the classroom is a timely and valuable way to engage students in science. People have used plants as medicines since at least the beginning of written history, with ancient Egyptian and Chinese texts describing medicinal uses of plants before 2500 BCE (Petrovska, 2012). The majority of the world's people use medicinal plants for some of their medical needs, and the World Health Organization (WHO) recognizes plant-based medicine as an essential component of health care (WHO, 2002).The use of plant-based medicines has skyrocketed in the United States in the past few decades, increasing from $2.5 \%$ in 1990 to $12.1 \%$ in 1997 (Eisenberg et al., 1998). In 2012, nearly 5\% of American children (Black et al., 2015) and 18\% of adults (Clarke et al., 2015) used a nonvitamin, non-mineral natural supplement.

Curricula and activities can be designed to give students the tools to improve scientific literacy and critically evaluate advertised health claims for plant-based medicines, which are unregulated dietary supplements in the United States. This classification means that, unlike pharmaceuticals, plant-based medicines can be produced and sold without safety and efficacy testing by the U.S. Food and Drug Administration (FDA; Institute of Medicine, 2005). Some argue that plant-based medicines have been used for many generations, are natural and safe, and do not need to be regulated as drugs. Others argue that this lack of regulation puts people at risk of harm or wastes money on ineffective treatments. However, the distinction between "safe" and "natural" is important, because detrimental side effects can exist in plant-based medicines due to the active ingredients, contamination, or interactions with pharmaceuticals (Bent, 2008); opium is a natural product too.

Because many medicinal plants have never been tested using the Western scientific method, laboratory investigations of plant-based medicines give students the opportunity to do authentic science, with real opportunities for scientific discovery. Integrating current scientific problems into the classroom is a good way for students to apply disciplinary core ideas, engage in science and engineering practices, and potentially make valuable contributions to science or their communities (Van Horne and Bell, 2015). Students in middle school or high school can design their own experiments or modify existing protocols with their own hypotheses to explore the effects of medicinal plants on bacteria or invertebrate animal models such as the worm Lumbriculus variegatus (Straus and Chudler, 2015).

People from all regions of the world have traditions that use medicinal plants for healing, and many students and their families currently use plant-based medicines. Examining the effects of these products in the classroom may be a way to bridge students' home and class experiences and make classroom learning more exciting, relevant, and empowering. Finally, the complex subject of plant-based medicine lends itself to alignment with the three dimensions of science learning in the Next Generation Science Standards (NGSS Lead States, 2013) as well as English Language Arts
CBE Life Sci Educ December 1, 2016 15:fe9 DOI:10.1187/cbe.16-06-0190

*Address correspondence to: Eric Chudler (chudler@u.washington.edu).

(C) 2016 K. M. Straus and E. H. Chudler. CBE-Life Sciences Education (c) 2016 The American Society for Cell Biology. This article is distributed by The American Society for Cell Biology under license from the author(s). It is available to the public under an Attribution-Noncommercial-Share Alike 3.0 Unported Creative Commons License (http://creativecommons.org/licenses/ by-nc-sa/3.0).

"ASCB®" and "The American Society for Cell Biology ${ }^{\circledR}$ " are registered trademarks of The American Society for Cell Biology. 
Common Core Standards (National Governors Association Center for Best Practices and Council of Chief State School Officers, 2010).

This Feature highlights Internet-based resources to help teachers in primary and secondary classrooms incorporate lessons and activities to teach about plant medicines. These Internet resources include curricula, videos, sites for students to explore for research projects, examples of science fair activities, and information about medicinal gardens.

\section{TEACHING RESOURCES: CURRICULA AND LESSONS}

Sowing the Seeds of Neuroscience (www.neuroseeds.org), a National Institutes of Health (NIH)-funded science education project, has developed eight lessons to teach middle school students about neuroscience through hands-on laboratory activities investigating the effects of medicinal plants on invertebrate animals (Figure 1). Materials for each lesson (accessible in the Lessons tab), include teacher guides with detailed curriculum plans, supply lists, and resources for additional learning, as well as student guides with reading, laboratory activities, and assessments. The lesson "Infusions and Decoctions: Preparing Plant Extracts" introduces the use of medicinal plants in the laboratory and includes a procedure to extract bioactive components from plants. Once students complete this extraction, they can use their plant extract in additional lessons to explore topics including the effects of herbs on bacterial reproduction, regeneration and movement in planaria worms, nervous system communication in cockroaches, and pulsation rate in $L$. variegatus worms. The Sowing the Seeds of Neuroscience resources page includes a variety of grouped topics such as plant stories that tell narratives about the history, ethnobotany, and medicinal value of plants, including St. John's wort, green tea, and catnip. This resource also includes a medicinal plants news archive with topics such as "Can chocolate be good for us?" and "Chili as a medicine and a weapon."

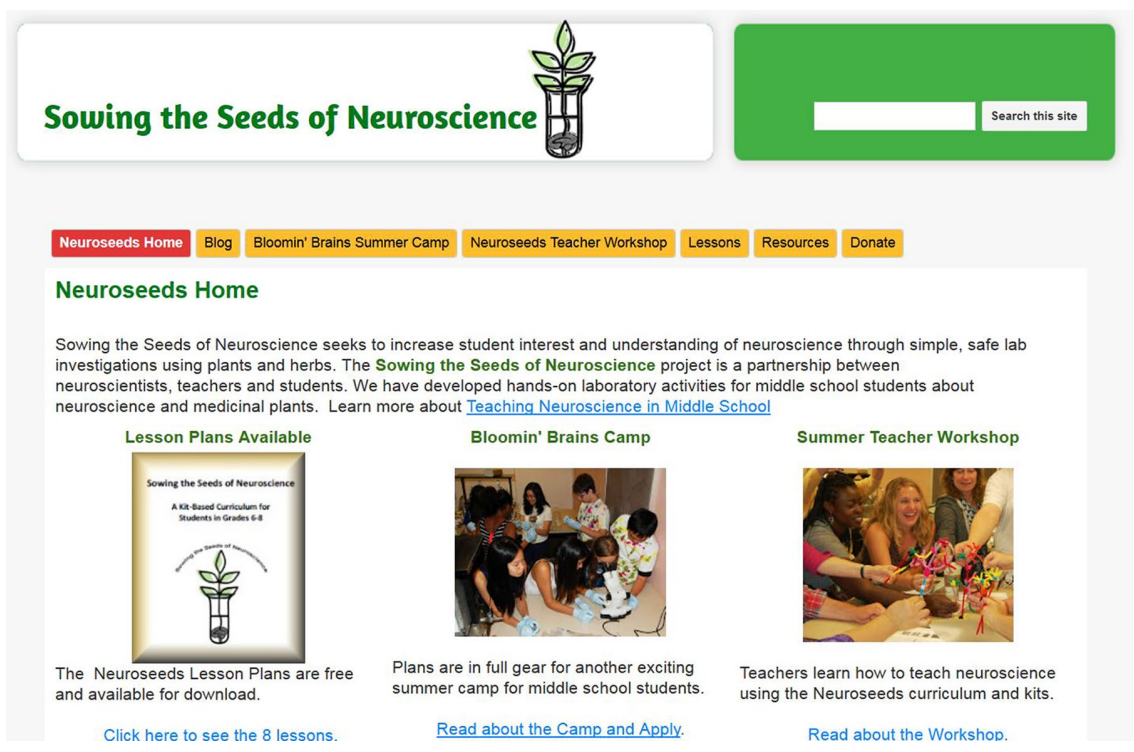

FIGURE 1. Sowing the Seeds of Neuroscience (www.neuroseeds.org) provides a free, downloadable eight-lesson curriculum designed to teach middle school students about neuroscience and medicinal plants through hands-on, laboratory investigations. This screenshot image is used with permission of Sowing the Seeds of Neuroscience.
The Learning Network from the New York Times (learning .blogs.nytimes.com) supports instruction via the New York Times newspaper. This site includes three lesson plans for teaching about ethnobotany and plant medicines. "Does Mother Nature Know Best?" is designed for students in grades 9-12 (learning .blogs.nytimes.com/1999/02/09/does-mother-nature -know-best/?_r=1; Zimbalist, 1999a). In this lesson, students take a survey about their perspectives on herbal medicine both before and after reading and discussing a New York Times article (Brody, 1999). Students can learn about safety and efficacy of a specific plant-based medicine and present their findings to their peers. A lesson with similar learning objectives designed for students in grades 6-8 is called "Herbs: Healthy Alternatives or Bad Medicine?" (learning.blogs.nytimes.com/2000/03/07/ herbs-healthy-alternatives-or-bad-medicine/\#more-2149; Zimbalist, 2000). A third lesson, "It's a Jungle Out There!," also geared toward sixth to eighth graders, is focused more broadly on the relationship between plants and people (learning.blogs .nytimes.com/1999/04/06/its-a-jungle-out-there; Zimbalist, 1999b). Students investigate the ways that different cultures use plants and explore ethnobotany by reading and discussing a New York Times article (Dreifus, 1999). Students can conduct online literature research by exploring one plant's life cycle, environmental requirements, and human uses. Finally, students are able to produce posters to share their new understanding with their peers. Each of these lesson plans contains extension activities and ideas for interdisciplinary connections.

The Fairchild Tropical Botanic Garden website provides downloadable teaching modules (www.fairchildgarden.org/ education/kids-families/downloadable-learning-modules\#eth) with teacher resources, student handouts, ideas for homework, laboratory investigations, and other classroom activities. The Ethnobotany unit examines the definition and scope of ethnobotany and explores ways in which humans interact with plants, from foods to medicines. Teachers can use classroom activities to connect ethnobotany to conservation, and students can produce two types of plant extracts used in a plant-pigment chromatography activity, and do and experiment to determine whether the plant has antibacterial properties. There are 14 additional activities, including crossword puzzles, case studies, a stakeholder analysis of medicinal rain forest plants, and an interview guide. Although not a full lesson plan, Exploring the Global Garden (www.rain .org/global-garden/science/ethnobotany -classroom-projects.html) has a list of ideas for ethnobotany activities in the classroom. The most intriguing activity may be the directions for making herbarium specimens by pressing, drying, and identifying plants.

"Ethnobotany and the Process of Drug Discovery: A Laboratory Exercise" (www .bioone.org/doi/pdf/10.1662/005.071 .0908 [requires a BioOne subscription]; Shelley, 2009) includes a lesson plan to teach high school and college students about medicinal plants and the importance 
of ethnobotanical research. Students select or are assigned a medicinal plant and conduct online ethnobotanical research to determine ecological information about the plant and historical and contemporary uses of the plant by specific cultures. Reliable Internet sources are suggested, many of which are also cited in this paper. In the laboratory, students learn about bioassays and the process of drug discovery by making extracts of the medicinal plants they researched and then testing their extracts in two assays (brine shrimp toxicity and microbial reproduction [disk diffusion]). The laboratory protocols are easy to follow and include a discussion of potential challenges in the classroom.

When learning about ethnobotany and medicinal plants, students may have questions about medicinal marijuana. Since 1970, the United States has classified marijuana as "Schedule I," which indicates that it has "no accepted medical use." However, 24 U.S. states and the District of Columbia have legalized medicinal marijuana. Clearly, this is a timely topic to explore in the classroom. Although there are many marijuana lesson plans available online, only a few focus on medicinal aspects. The learning blog from the New York Times has a lesson plan called "Altered States: Reflecting on State Medical Marijuana Laws." (http://learning.blogs.nytimes.com/2009/12/04/altered-states -reflecting-on-state-medical-marijuana-laws/?r=0; Doyne and Ojalvo, 2009). In this lesson, sixth- to twelfth-grade students examine social, legal, economic, and ethical issues related to medicinal marijuana. Students read a New York Times article and watch an 8-minute video, develop questions to pursue, do online research, and then discuss the broad ramifications of medical marijuana legalization. Websites are recommended, and strategies for gauging the reliability of Internet information are included to share with students. Scholastic also provides a short lesson plan, including reading, a worksheet, and a teacher guide called "The Myth of Medical Marijuana" (http://headsup .scholastic.com/sites/default/files/block/images/NIDA10 -INS3_TE.pdf). This lesson focuses on the process for approving medicines in the United States and explains that marijuana is not medicine because it has not gone through the approval process.

Students interested in researching medicinal marijuana will find ProCon.org useful. ProCon.org "explores the pros and cons of controversial issues," and the medical marijuana site (medicalmarijuana.procon.org) is a rich collection of information regarding overall medical value, value for specific diseases, risks to specific populations, history, legal issues, access, and more.

TEACHING RESOURCES: SITES FOR STUDENT RESEARCH

Some teachers may prefer not to give students free rein to research medicinal plants on the Internet because so much misinformation exists online. The following sites are reputable places to gather information about ethnobotany and plant-based medicines. The University of Maryland Medical Center maintains a website that explores complementary and alternative medicines, the wide range of medical therapies that fall beyond the scope of conventional medicine including plant-based medicine. The overview page about herbal medicine (umm.edu/ health/medical/altmed/treatment/herbal-medicine) is a useful starting point for teachers or students beginning to learn about plant-based medicines. This page includes a short history of herbal medicine and descriptions of the uses, efficacy, and side effects of six medicinal plants commonly taken in the United
States. The complementary and alternative medicine guide includes a list of herbs that, when clicked, expands to provide additional information. Descriptions of each herb include an overview about how it has been used by people of different cultures, a summary of the parts used, available forms and how to take it, medicinal uses, precautions, interactions, and supporting research. The site is highly readable and accessible to teachers and high school students.

The mission of the NIH Office of Dietary Supplements (ODS; ods.od.nih.gov) includes "strengthening knowledge and understanding of dietary supplements ... and educating the public." One way ODS provides education is its website, which provides excellent introductory material to explain how dietary supplements are defined, labeled, and regulated by the FDA. The site's Frequently Asked Questions page and research-based "fact sheets" detail individual supplements from acai to zinc. The ODS page on botanical dietary supplements is devoted to plantbased medicines, including definitions, a description of the ways these medicines are commonly prepared, and information about efficacy and safety. A Spanish-language version of the ODS site is also available.

The National Center for Complementary and Integrative Health (NCCIH) is the U.S. government's primary agency for scientific research on medical products and healthcare approaches that are not considered conventional medicine. The NCCIH website (nccih.nih.gov) includes definitions of terms and links for research-based information about medicinal plants as well as other alternative approaches such as acupuncture. The Herbs at a Glance link (nccih.nih.gov/health/herbsataglance .htm) provides "fact sheets" with information about specific plant-based medicines, including common names and what research indicates about efficacy, safety, and side effects. Three additional pages may be particularly helpful for students exploring the use of supplements as alternative medicine: Using Dietary Supplements Wisely, Know the Science: How Medications and Supplements Can Interact, and Know the Science: 9 Questions to Help You Make Sense of Health Research.

Examine.com (examine.com/supplements) describes itself as an "independent and unbiased encyclopedia on supplementation and nutrition." Its goal is to collate the latest scientific research into a readable, accessible resource. Although this is a dot-com site with a store tab, the free information provided is an excellent resource. Information about different plant-based medicines and supplements is backed with references to scientific papers. The garlic page, for example, references 638 different peer-reviewed papers, many of which can be accessed directly through a PubMed link. Each supplement page is divided into a Summary page, a Things to Know page, and a Citations page. The most interesting feature is the "human effect matrix," which includes information from human studies that measure the effects of the medicinal plant on the human body. This table lists what the research examined, what the results indicate, and a confidence level of the research from the highest (robust, repeated, double-blind clinical trials) to the lowest levels (uncontrolled or observational studies only).

The Cancer Research UK page (www.cancerresearchuk.org/ about-cancer/cancers-in-general/treatment/complementary -alternative/therapies/herbal-medicine) can be used by students conducting literature-based research projects about herbal medicine and cancer. This site covers similarities and 


\section{EthnoHerbalist}

\section{We review the history and health benefits of medicinal plants.}

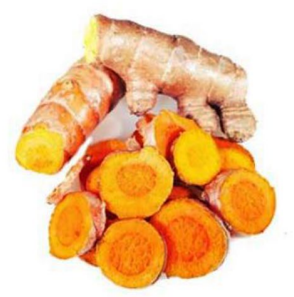

Turmeric

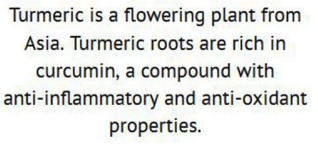

Turmeric is a flowering plant from Turmeric roots are rich in curcumin, a compound with properties.

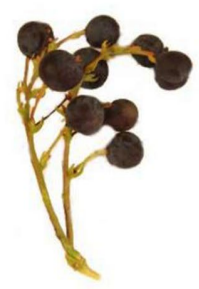

Black Elderberry

Black elderberry is a flowering tree native to Europe. The plant contains compounds that boosts our immune system, helping us stay healthy during the cold and flu season.

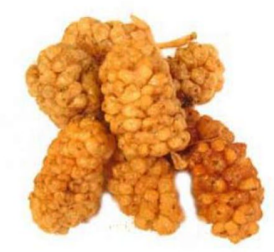

White Mulberry

White mulberry is a tree from China. The leaves and fruits are high in fiber and protein and can help lower our blood-sugar levels.
FIGURE 2. The EthnoHerbalist website (www.ethnoherbalist.com/) describes the ethnobotany of Southern California and details the history, use, and relevant research about health benefits and biochemistry of nine medicinal plants. This screenshot image is used with permission of EthnoHerbalist.

differences between Western and Chinese herbal medicine, explores why people with cancer might use herbal medicine, and what herbs are taken most often. Information about research, side effects, cost, and "things to consider" are included for six herbs commonly used by people with cancer.

The EthnoHerbalist website (www.ethnoherbalist.com) is composed of a tab on common medicinal plants and a tab on the ethnobotany of Southern California (Figure 2). The Ethnobotany tab includes an overview of Native American groups in Southern California and a list of plants used for medicine, shelter, and food by Native Americans in this area. Although restricted to a small region, this site might be useful outside of Southern California as a readable and engaging example of ethnobotany. Students may research the ethnobotany of their region with the goal of developing a similar resource of their own. The Medicinal Plants tab focuses on nine medicinal plants for which high-quality clinical trials suggest efficacy for specific health concerns. The writing style of the EthnoHerbalist is conversational and includes many photographs. However, this is the only site we recommend that includes links for purchasing plant-based medicines, and the owner of the site receives an affiliate commission for any purchases made through these links. We have included this Web resource primarily because the Ethnobotany section of this site is a unique and valuable resource.

Culturally interested students can turn to the NIH Native Voices site (www.nlm.nih.gov/nativevoices) for videos and writing by Native Americans (American Indians, Alaska Natives, and Native Hawaiians) sharing stories about health, sickness, and healing. The healing plants portion of this site (www.nlm.nih.gov/nativevoices/exhibition/healing-ways/ medicine-ways/healing-plants.html) explores the long history and current Native American use of plants as medicine. The site has a short introduction with information about medicinal plants grouped by region. More information can be obtained about the uses of each plant by clicking on its image. The Interviews tab showcases a collection of videos exploring the diversity of ideas contributing to wellness in Native American communities. There is also a lesson plan designed for grades 6-8 about indigenous perspectives on health and healing (www.nlm.nih.gov/nativevoices/ resources/resourcedocs/Indigenous PerspectiveHealing.pdf). After completing the lesson, students should be able to identify medicinal plants used by Native Americans and describe their uses, compare and contrast healing practices and the role of healers in indigenous societies with their own communities, and identify pharmaceutical medicines with ingredients from medicinal plants.

Students more interested in conservation science may find that medicinal plants make good case studies. Traffic (www .traffic.org/overview) is an international nongovernmental organization that monitors and regulates trade in wild animals and plants to conserve biodiversity while helping communities develop sustainably (Figure 3). Traffic's medicinal plants program (www.traffic .org/medicinal-plants) supports best practices in harvesting wild medicinal plants to support biodiversity conservation as well as health and sustainable livelihoods. The site includes easy-to-read text and photos about harvest, use, and trade of wild plants; information about the sustainable certification program FairWild Standard for wild medicinal and aromatic plants; a link for the latest news on medicinal and aromatic plants; and a short video (Healing Power from Nature). Mongabay is a news and information site focused on environmental science and conservation. Mongabay includes a page about rain forest medicinal plants (rainforests.mongabay.com/1007.htm) as the "ultimate chemical laboratory" and the likelihood of discovering tropical plants with medicinal value in the future. Mongabay explores indigenous uses of plants, highlights the process of biomedical screening of plant compounds for anticancer activity, and addresses the ethics of companies patenting plant compounds that are used traditionally by indigenous communities (biopiracy). For students interested in pharmaceutical drugs made from plants, a 2016 list can be accessed from About Chemistry (chemistry.about.com/od/medicalhealth/fl/Drugs -from-Plants.htm; Helmenstine, 2016). Additionally, the U.S. Department of Agriculture (agresearchmag.ars.usda.gov/1998/ apr/drug) describes ways that medicinal compounds are isolated from plants.

Many databases contain information about plant-based medicines, plant compounds used in pharmaceuticals, and ethnobotany. The Native American Ethnobotany Database (http://naeb.brit.org) is searchable by either tribe or plant and contains a great deal of information. For example, 119 results 

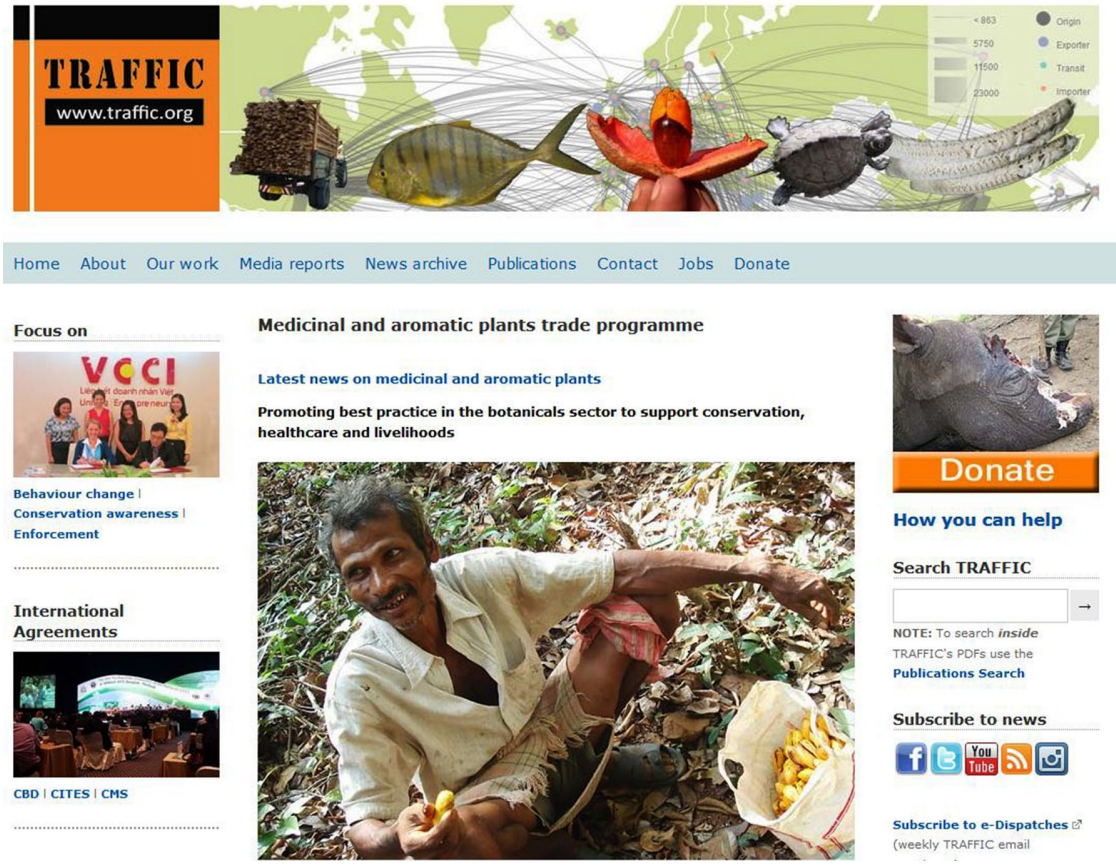

FIGURE 3. The Traffic medicinal and aromatic plant program (www.traffic.org/ medicinal-plants/) monitors, regulates, and certifies sustainably harvested plants in order to support biodiversity conservation and sustainable community development. This screenshot image is used with the permission of Traffic.

are returned for "Echinacea" and more than 3000 results are returned for "Cherokee." Each result includes the Native American tribe that uses this plant as medicine, the way it was used, and a citation. Dr. Duke's Phytochemical and Ethnobotanical Databases (phytochem.nal.usda.gov/phytochem/help/index/ about) includes a list of phytochemical constituents of many medicinal plants. Several academic journals might be useful but may not be open access, so students might need to search authors' free Web postings. These journals include the Annals of the Missouri Botanical Garden (www.bioone.org/loi/mobt), Economic Botany (www.econbot.org), the Journal of Ethnobiology (ethnobiology.org/publications/journal), the Journal of Ethnopharmacology (www.journals.elsevier.com/journal -of-ethnopharmacology), and the Journal of Ethnobiology and Ethnomedicine (ethnobiomed.biomedcentral.com).

\section{TEACHING RESOURCES: EXTENSIONS}

Teachers who have students interested in conducting further experiments on medicinal plants should direct them to Julian's Science Fair website for alternative medicine (www .juliantrubin.com/fairprojects/medicine/alternativemedicine .html). The site lists project (P) and experiment (E) ideas categorized by grade. Clicking on a letter (P or E) links to student-created project websites or California State Science Fair summaries. There are more than 50 experiments and projects detailed such as "Which Spice Inhibits Bacterial Growth Best?" (elementary school), "Green Tea: Do More Expensive Green Teas Have a Better Medical Effect" (middle school), and "A Study on the Anti-mutagenic Effects of Turmeric" (high school). Students can use these examples as starting points from which to explore their own questions about medicinal plants used by their families, communities, or ancestors.

School gardens provide significant benefits, including increased consumption of fresh fruits and vegetables (e.g., Canaris, 1995; Pothukuchi, 2004) and significantly higher scores on science achievement tests (Klemmer et al., 2005; Dirks and Orvis, 2005; Smith and Motsenbocker, 2005). School gardens would be a great extension activity for students of all ages. Life Lab (www.lifelab.org/about) uses gardening to nurture children's love of learning, nutritious food, and nature (Figure 4). A For Educators tab includes professional development opportunities, curricula, lesson plans, information about building and maintaining school gardens, webinars, and a YouTube channel with more than 100 videos about gardening education (www.youtube.com/user/lifelabvideos). One of the most valuable components of this website is the thorough alignment of garden-based learning with the Next Generation Science Standards (NGSS Lead States, 2013) and the Common Core Standards (National Governors Association Center for Best Practices and Council of Chief State School Officers, 2010; www.lifelab.org/content-standards). KidsGardening.org (www .kidsgardening.org) includes a teacher resources section with free downloadable lesson plans; books and curricula to purchase; a toolbox for designing, creating, and sustaining school gardens; and information about their "youth garden grants." Fairchild Tropical Botanic Garden (www.fairchildgarden.org/ education/kids-families/downloadable-learning-modules) also includes resources for designing, implementing, and maintaining school gardens in addition to elementary and secondary lesson plans for using the garden in curriculum. Although these sites do not include information specific to medicinal plants, they contain valuable details for creating any school garden. Some school gardens, such as the Learning Garden in Venice High School (www.thelearninggarden.org), include a large medicinal plant section. If possible, a field trip to a medicinal garden may be valuable for students learning about ethnobotany and medicinal plants. To find such resources locally, one could start by exploring local natural history museums, horticultural and garden societies, botanical gardens, and universities.

To learn about planning and planting a medicinal plant garden, the Homestead Lady site (Figure 5) is quite useful (www.homesteadlady.com/how-to-plan-and-plant-a-medicinal -herb-garden). This site includes specific sun and soil requirements for different plants, where to buy seeds for medicinal plants, and the differences between seeds and starts. A companion post (www.homesteadlady.com/must-have-must-grow -medicinal-herbs) includes information on the top nine medicinal plants to grow, culture requirements, and medicinal uses. Homestead Lady includes links to items for purchase, and the owner of this site receives an affiliate commission for any purchases made through these links. We have chosen to include 

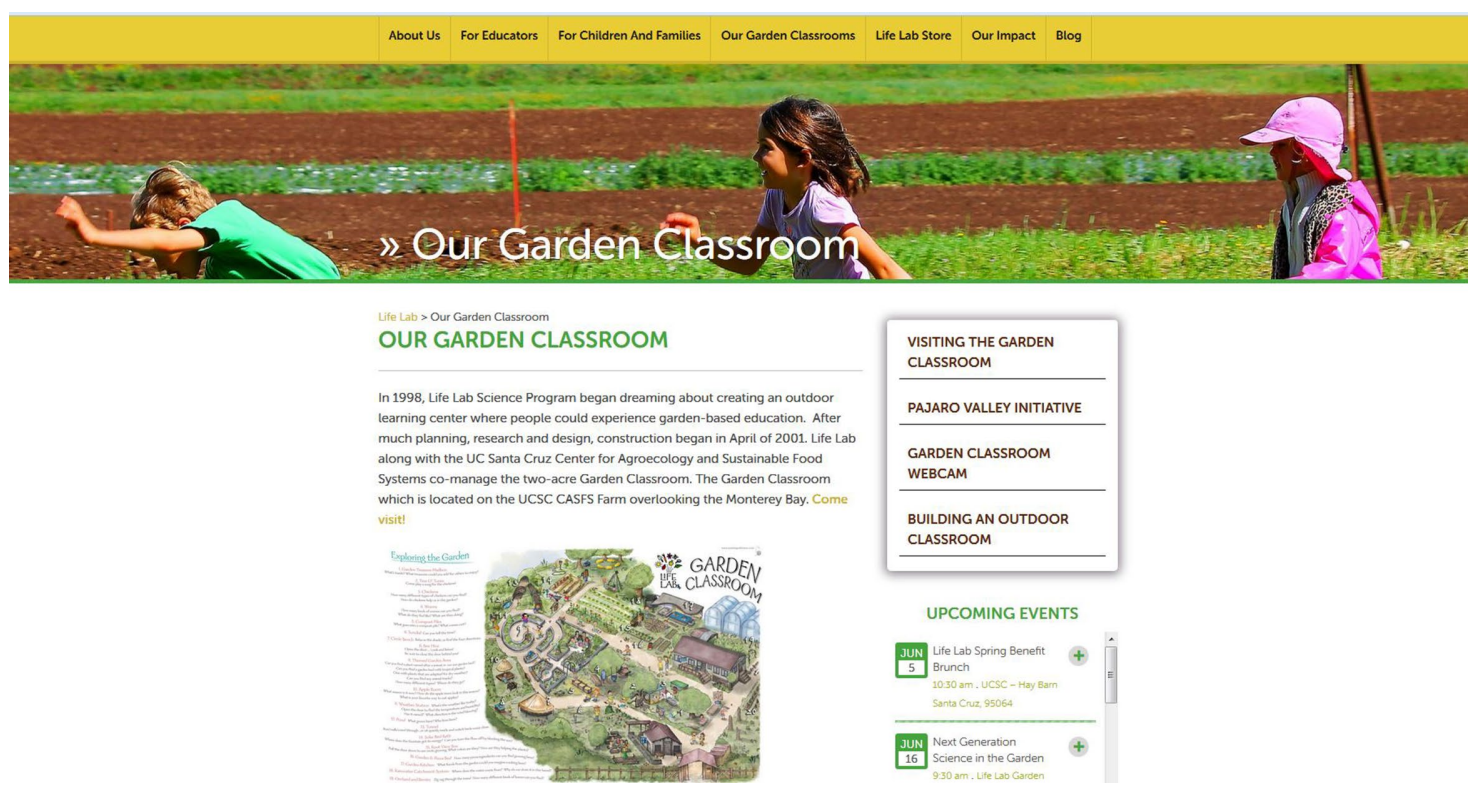

FIGURE 4. LifeLab (www.lifelab.org/about/) explains how and why to create school gardens and provides information, lesson plans, and videos for educators to develop garden-based curricula. This screenshot image is used with permission of LifeLab.

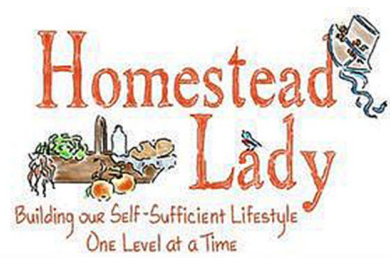

Home Start Here Blog shop Subscribe About Us contact

How to plan and plant a Medicinal Herb Garden Posesd on March 2, 2013 by Homescead Lady

A Merry Heart Doeth Good Like a Medicine - Spread the Joy \& Share the Post! PfOB \& 8

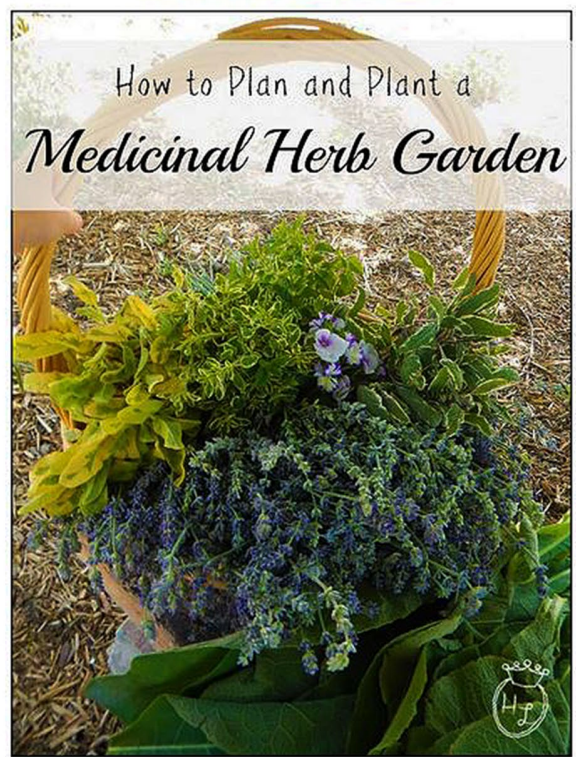

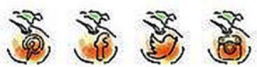

Search Our Site

Search Ste a

Popular Posts

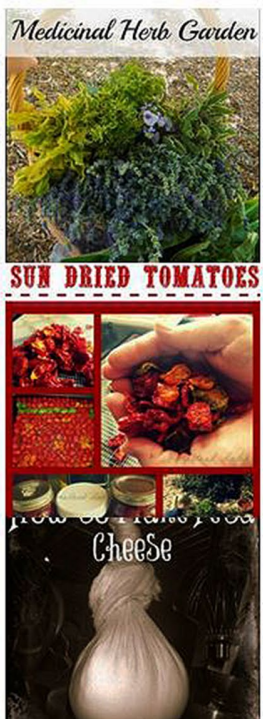

this site because the detailed information on planning, planting, and maintaining medicinal gardens is valuable and not available elsewhere.

\section{CONCLUSION}

The variety of online resources including curricula, laboratory investigations, school garden ideas, and science fair projects provides excellent opportunities for educators and students to explore the field of medicinal plants and ethnobotany. These topics are appropriate for learners of all ages and can be aligned with the Next Generation Science Standards (NGSS Lead States, 2013; Table 1) and the English Language Arts Common Core Standards (National Governors Association Center for Best Practices and Council of Chief State School Officers, 2010; Table 2). In all of the laboratory-based activities, students will practice planning and carrying out investigations, engaging in argument from evidence, and analyzing and interpreting data.

FIGURE 5. Homestead Lady (www .homesteadlady.com/how-to-plan-and -plant-a-medicinal-herb-garden/) includes information for planning, planting, and caring for medicinal plant gardens. This screenshot image is used with permission of the Homestead Lady. 
Students can also use critical-thinking skills to evaluate claims made by the plant-based medicine suppliers, to determine whether observations supported their hypotheses, and to draw connections between medicinal plant harvest, biodiversity, and sustainability. Additionally, the exploration of medicinal plants could lead to authentic scientific discovery and may empower students as they research the ethnobotany of plants used by their family and ancestors.

TABLE 1. Example three-dimensional alignments for using medicinal plants and ethnobotany with the Next Generation Science Standards (NGSS Lead States, 2013)

\begin{tabular}{|c|c|c|c|c|}
\hline Grade & Dimension & Standard & Sample student task & Reference \\
\hline $6-8$ & DCI & $\begin{array}{l}\text { MS-LS1.A: Structure and } \\
\text { Function }\end{array}$ & $\begin{array}{l}\text { Describe what is happening in the } \\
\text { nervous and cardiovascular systems of } \\
\text { the worm when exposed to this plant } \\
\text { extract. }\end{array}$ & www.neuroseeds.org/Lessons/heartthrobs \\
\hline $6-8$ & DCI & $\begin{array}{l}\text { MS-LS1.D: Information } \\
\text { Processing }\end{array}$ & $\begin{array}{l}\text { Does the nervous system in planaria } \\
\text { respond to chemical stimuli? How do } \\
\text { you know? }\end{array}$ & www.neuroseeds.org/Lessons/wormmove \\
\hline $6-8$ & DCI & $\begin{array}{l}\text { MS-LS1.B: Growth and } \\
\text { Development of } \\
\text { Organisms }\end{array}$ & $\begin{array}{l}\text { Was your plant extract effective at } \\
\text { preventing bacterial growth? How do } \\
\text { you know? }\end{array}$ & $\begin{array}{l}\text { www.neuroseeds.org/Lessons/superhe- } \\
\text { roes }\end{array}$ \\
\hline $9-12$ & DCI & $\begin{array}{l}\text { HS-LS4.D: Biodiversity and } \\
\text { Humans }\end{array}$ & $\begin{array}{l}\text { How are the natural supplies of some } \\
\text { herbs becoming endangered due to } \\
\text { the popularity of herbal supplements, } \\
\text { and what might this mean for the } \\
\text { future of the industry and of the } \\
\text { earth? }\end{array}$ & $\begin{array}{l}\text { http://learning.blogs.nytimes } \\
\text {.com/1999/02/09/does-mother } \\
\text {-nature-know-best/?_r=2 }\end{array}$ \\
\hline 1 & DCI & $\begin{array}{l}\text { 1-LS1.A: Structure and } \\
\text { Function }\end{array}$ & $\begin{array}{l}\text { Explore the school garden to look at a } \\
\text { variety of leaves and stems. Why are } \\
\text { leaves important? Would the plant } \\
\text { grow without them? }\end{array}$ & $\begin{array}{l}\text { www.lifelab.org/wpcontent/ } \\
\text { uploads/2010/02/ } \\
\text { 1stPonderingPlants2012.pdf }\end{array}$ \\
\hline 2 & DCI & $\begin{array}{l}\text { 2-LS2.A: Interdependent } \\
\text { Relationships in } \\
\text { Ecosystems }\end{array}$ & $\begin{array}{l}\text { Match flowers to the kind of pollinators } \\
\text { they attract and then observe } \\
\text { different-shaped flowers in the garden } \\
\text { and the animals that visit them. }\end{array}$ & $\begin{array}{l}\text { www.lifelab.org/wpcontent/ } \\
\text { uploads/2010/02/ } \\
\text { 3rdGardenPollinators2016.pdf }\end{array}$ \\
\hline $9-12$ & SEP & $\begin{array}{l}\text { Planning and Carrying Out } \\
\text { Investigations }\end{array}$ & $\begin{array}{l}\text { Decide which plant extract to test, } \\
\text { develop a hypothesis about its toxicity } \\
\text { on brine shrimp, and complete this } \\
\text { investigation. }\end{array}$ & Shelley (2009) \\
\hline $6-8$ & SEP & $\begin{array}{l}\text { Engaging in Argument from } \\
\text { Evidence }\end{array}$ & $\begin{array}{l}\text { Did your observations support or refute } \\
\text { your hypothesis? What evidence do } \\
\text { you have? }\end{array}$ & www.neuroseeds.org \\
\hline $\mathrm{K}-5$ & SEP & $\begin{array}{l}\text { Analyzing and Interpreting } \\
\text { Data }\end{array}$ & $\begin{array}{l}\text { Does your plant extract kill the bacteria } \\
\text { that turn milk into yogurt? How do } \\
\text { you know? }\end{array}$ & $\begin{array}{l}\text { www.fairchildgarden.org/portals/0/docs/ } \\
\text { education/downloadable_teaching_ } \\
\text { modules/ethnobotany/ethnobot- } \\
\text { any\%20extracts\%20and\%20tinctures } \\
\text {.pdf?ver=2015-10-19-103051-243 }\end{array}$ \\
\hline $6-8$ & SEP & $\begin{array}{l}\text { Obtaining, Evaluating, } \\
\text { and Communicating } \\
\text { Information }\end{array}$ & $\begin{array}{l}\text { Investigate the reported effects and } \\
\text { warnings about specific herbal and } \\
\text { pharmaceutical remedies used to treat } \\
\text { common ailments. Share your results } \\
\text { by creating and presenting a poster to } \\
\text { your classmates. }\end{array}$ & $\begin{array}{l}\text { http://learning.blogs.nytimes. } \\
\text { com/2000/03/07/herbs-healthy } \\
\text {-alternatives-or-bad-medicine/ } \\
\text { \#more-2149 }\end{array}$ \\
\hline $6-8$ & CC & Cause and Effect & $\begin{array}{l}\text { Based on your class data, how would you } \\
\text { predict coffee (or another untested } \\
\text { stimulant) affects nerve cell communi- } \\
\text { cation in cockroaches? }\end{array}$ & www.neuroseeds.org/Lessons/spikerbox \\
\hline $\mathrm{K}-12$ & CC & Structure and Function & $\begin{array}{l}\text { Any close examination of structures and } \\
\text { discussion or testing to determine } \\
\text { function }\end{array}$ & Many \\
\hline
\end{tabular}

Disciplinary Core Idea = DCI, Science and Engineering Practices $=$ SEP, and Crosscutting Concepts $=$ CC. 
TABLE 2. Example English Language Arts Common Core standards (National Governors Association Center for Best Practices \& Council of Chief State School Officers, 2010)

\begin{tabular}{|c|c|c|}
\hline Grade & Standard code & Standard text \\
\hline $6-8$ & RST.6-8-1 & Cite specific textual evidence to support analysis of science and technical texts. \\
\hline $6-8$ & RST.6-8-3 & $\begin{array}{l}\text { Follow precisely a multistep procedure when carrying out experiments, taking measurements, or performing } \\
\text { technical tasks. }\end{array}$ \\
\hline $9-10$ & RST.9-10 $0^{-1}$ & $\begin{array}{l}\text { Cite specific textual evidence to support analysis of science and technical texts, attending to the precise details of } \\
\text { explanations or descriptions. }\end{array}$ \\
\hline $9-10$ & WHST.9-10-2d & $\begin{array}{l}\text { Use precise language and domain-specific vocabulary to manage the complexity of the topic and convey a style } \\
\text { appropriate to the discipline and context as well as to the expertise of likely readers. }\end{array}$ \\
\hline $11-12$ & RST.11-12.1 & $\begin{array}{l}\text { Cite specific textual evidence to support analysis of science and technical texts, attending to important distinctions } \\
\text { the author makes and to any gaps or inconsistencies in the account. }\end{array}$ \\
\hline $11-12$ & RST.11-12.3 & $\begin{array}{l}\text { Follow precisely a complex multistep procedure when carrying out experiments, taking measurements, or } \\
\text { performing technical tasks; analyze the specific results based on explanations in the text. }\end{array}$ \\
\hline
\end{tabular}

These standards relate to reading scientific texts and following directions in laboratory investigations.

\section{ACKNOWLEDGMENTS}

This work was supported by the NIH Blueprint for Neuroscience Research and administered by the National Institute on Drug Abuse through grant number R25DA033011. We thank Malcolm Campbell and Kristen C. Bergsman for their useful editorial comments and suggestions.

\section{REFERENCES}

Bent S (2008). Herbal medicine in the United States: review of efficacy, safety, and regulation. J Gen Int Med 23, 854-859.

Black LI, Clarke TC, Barnes PM, Stussman BJ, Nahin RL (2015, February 10). Use of complementary health approaches among children aged 4-17 years in the United States: National health interview survey, 2007-2012. Natl Health Stat Report 78, 1-19.

Brody JE (1999, February 9). Americans gamble on herbs as medicine. New York Times.

Canaris I (1995). Growing foods for growing minds: integrating gardening and nutrition education into the total curriculum. Child Environ 12, 134-142.

Clarke TC, Black LI, Stussman BJ, Barnes PM, Nahin RL (2015, February 10) Trends in the use of complementary health approaches among adults: United States, 2002-2012. Natl Health Stat Report 79, 1-16.

Dirks AE, Orvis K (2005). An evaluation of the junior master gardening program in third grade classrooms. HortTechnology 15, 443-447.

Doyne S, Ojalvo HE (2009, December 4). Altered states: reflecting on state medical marijuana laws. Learning Network: Teaching and Learning with the New York Times (blog). http://learning.blogs.nytimes.com/2009/12/04/ altered-states-reflecting-on-state-medical-marijuana-laws/?r=0\&_r=0 (accessed 6 June 2016).

Dreifus C (1999, April 6). A conversation with: Michael J. Balick; New York's a jungle, and one scientist doesn't mind. New York Times.

Eisenberg DM, Davis RB, Ettner SL, Appel S, Wilkey S, Van Rompay M, Kessler RC (1998). Trends in alternative medicine use in the United States, 1990 1997. J Am Med Assoc 280, 1569-1575.

Helmenstine AM (2016, April 1). Drugs and medicine made from plants. http://chemistry.about.com/od/medicalhealth/fl/Drugs-from-Plants htm (accessed 23 October 2016).
Institute of Medicine (2005). Dietary Supplements: A Framework for Evaluating Safety, Washington, DC: National Academies Press.

Klemmer CD, Waliczek TM, Zajicek JM (2005). Growing minds: the effect of a school gardening program on the science achievement of elementary students. HortTechnology 15, 448-452.

National Governors Association Center for Best Practices and Council of Chief State School Officers (2010). Common Core State Standards, Washington, DC.

Next Generation Science Standards Lead States (2013). Next Generation Science Standards: For States, By States, Washington, DC: National Academies Press.

Petrovska BB (2012). Historical review of medical plants' usage. Pharmacogn Rev 6, 1-5.

Pothukuchi K (2004). Hortaliza: a youth "nutrition garden" in southwest Detroit. Child Youth Environ 14, 124-155.

Shelley BCL (2009). Ethnobotany and the process of drug discovery: a laboratory exercise. Am Biol Teach 71, 541-547.

Smith LL, Motsenbocker CE (2005). Impacts of hands on science through school gardening in Louisiana public elementary schools. HortTechnology $15,439-443$.

Straus KM, Chudler EH (2015). Botanical heart throbs: heart rate in blackworms. Sci Scope 39, 26-31.

Van Horne K, Bell P (2015). Why should students investigate contemporary science topics-and not just "settled" science? http://stemteachingtools org/brief/2 (accessed 28 May 2016).

World Health Organization (2002). Traditional Medicine Strategy 2002-2005, Geneva.

Zimbalist A (1999a, February 9). Does Mother Nature know best? Learning Network: Teaching and Learning with the New York Times (blog). http:// learning.blogs.nytimes.com/1999/02/09/does-mother-nature-know -best/?_r=2 (accessed 1 May 2016).

Zimbalist A (1999b, April 6). It's a jungle out there! Learning Network: Teaching and Learning with the New York Times (blog). http://learning.blogs.nytimes .com/1999/04/06/its-a-jungle-out-there/ (accessed 1 May 2016).

Zimbalist A (2000, March 7). Herbs: healthy alternatives or bad medicine? Learning Network. Teaching and Learning with the New York Times. http://learning.blogs.nytimes.com/2000/03/07/herbs-healthy-alternatives -or-bad-medicine/\#more-2149 (accessed 1 May 2016). 